
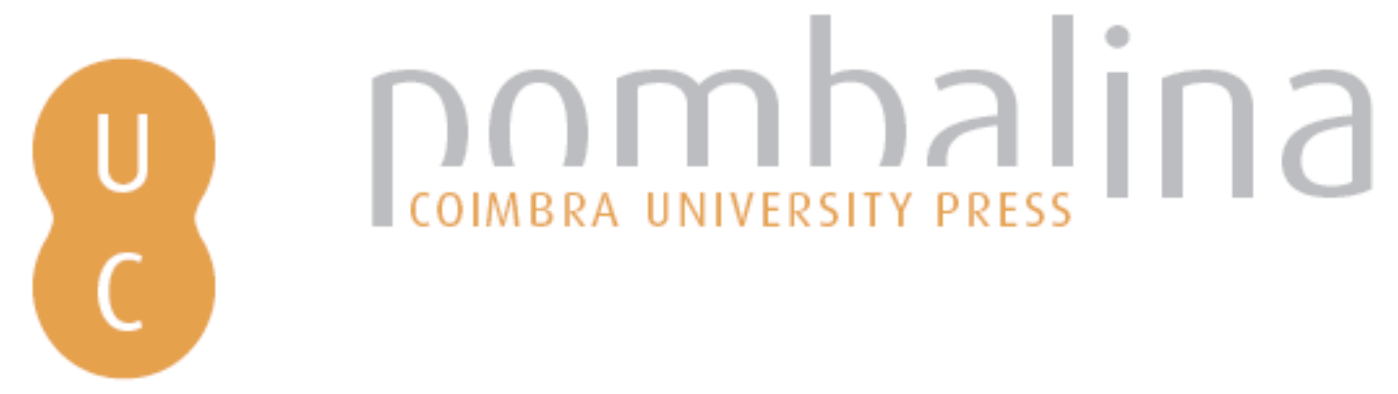

\title{
Development of strenght parameters during childhood and youth: a longitudinal study from Cariri, Brazil
}
Autor(es): $\quad$ Adam; Prista, António; Freitas, Duarte; Seabra, André; Garganta, Rui;
Silva, Simonete; Beunen, Gaston; Claessens, Albrecht; Baxter-Jones, Maia, José

Publicado por: Imprensa da Universidade de Coimbra

URL persistente:

URI:http://hdl.handle.net/10316.2/38547

DOI:

DOI:http://dx.doi.org/10.14195/978-989-26-0773-3_5

Accessed : $\quad$ 26-Apr-2023 12:17:55

A navegação consulta e descarregamento dos títulos inseridos nas Bibliotecas Digitais UC Digitalis, UC Pombalina e UC Impactum, pressupõem a aceitação plena e sem reservas dos Termos e Condições de Uso destas Bibliotecas Digitais, disponíveis em https://digitalis.uc.pt/pt-pt/termos.

Conforme exposto nos referidos Termos e Condições de Uso, o descarregamento de títulos de acesso restrito requer uma licença válida de autorização devendo o utilizador aceder ao(s) documento(s) a partir de um endereço de IP da instituição detentora da supramencionada licença.

Ao utilizador é apenas permitido o descarregamento para uso pessoal, pelo que o emprego do(s) título(s) descarregado(s) para outro fim, designadamente comercial, carece de autorização do respetivo autor ou editor da obra.

Na medida em que todas as obras da UC Digitalis se encontram protegidas pelo Código do Direito de Autor e Direitos Conexos e demais legislação aplicável, toda a cópia, parcial ou total, deste documento, nos casos em que é legalmente admitida, deverá conter ou fazer-se acompanhar por este aviso.

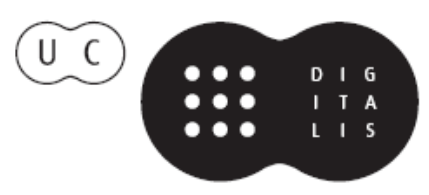




\section{GROWTH AND \\ MATURATION \\ IN HUMAN BIOLOGY \\ AND SPORTS}

FESTSCHRIFT HONORING ROBERT M. MALINA

BY FELLOWS AND COLLEAGUES

PETER TODD KATZMARZYK MANUEL J COELHO E SILVA

EDITORS 


\title{
DEVELOPMENT OF STRENGTH PARAMETERS DURING CHILDOOD AND YOUTH: A LONGITUDINAL STUDY FROM CARIRI, BRAZIL
}

\author{
Simonete Silva \\ Gaston Beunen \\ Albrecht Claessens \\ Adam Baxter-Jones \\ António Prista \\ Duarte Freitas \\ André Seabra \\ Rui Garganta \\ José Maia
}

\section{INTRODUCTION}

Longitudinal studies of motor performance, particularly pertaining to strength parameters, describing children and adolescents development are limited in the pediatric exercise science literature. For example, a review of changes in motor performance from a variety of tasks in boys and girls, followed for several years, was reported by Malina et al. (2004). However, many of the studies reviewed were conducted some 10-20 years prior to publication. In addition, no formal modeling or hypothesis testing were produced to interpret performance changes presented in the review. Within the European mainstream, the best approach to describe repeated information concerning motor performance was performed by Beunen et al. (1988). They provided distance and velocity charts for several motor tests (flamingo balance, plate tapping, sit and reach, vertical jump, standing long jump, arm pull, leg lifts, sit ups, shuttle run $50 \mathrm{~m}$, and shuttle run $480 \mathrm{~m}$ ) for Belgian boys followed over 6 years from 12 to 18 years of age.

Seminal work about static strength changes during youth was reported by Carron and Bailey (1974). They followed 99 Canadian boys from 10 to 16 years of age, using seven static strength tests. They found that maximum strength increments occurred I year after peak height velocity and peak weight velocity. Early maturers had significantly greater strength than late maturers. However, when strength was divided by body height, the results remained unchanged. Furthermore, when the effects of weight were factored out, no differences remained among groups of different maturational levels. In Belgian boys, Beunen et al. (1988) showed that static strength (arm pull test) increased fairly linearly with chronological age from early childhood to approximately 12 or 13 years of age. On the other hand explosive strength performance (standing long jump test), and on average, increased linearly with age in both sexes until 12 years in girls, and 13 years in boys. In contrast to girls, in boys, a clear growth spurt in explosive strength was seen to occur, 6 months after age at peak height velocity and coincided with peak weight velocity. In both sexes, size, body composition and biological maturation were associated with strength 
characteristics, although the magnitude of correlations varied with sex, age and the strength component (Malina, Bouchard \& Bar-Or, 2004).

An adequate understanding of the dynamics of changes in performance necessarily implies the use of longitudinal and/or mixed-longitudinal designs; and the use of flexible statistical models. This is because the effects of maturation may mask of be greater than the effects of growth per say. The description and interpretation of the dynamics of change, its patterns, as well as the use of relevant covariates that can explain the magnitude and direction of change is mostly lacking (Baxter-Jones, Sherar \& Eisenmann, 2005; Beunen et al., 1988; Maia et al., 2005). Fortunately, developments in the statistical theory of hierarchical linear models (HLMs) enables the integration of the study of the complexities of individual growth, group description and investigation of correlates of status and change (Bryk \& Raudenbush, 1987; Hox, 2010).

To our knowledge no recent longitudinal studies have attempted to describe or interpret changes in strength development or identify what variables predicts theses changes. This study aims to describe strength development obtained from a variety of motor performance tasks observed in Brazilian children and youth to: (I) model changes in strength performance of children and youth of four cohorts followed longitudinally from 8 to 16 years; (2) verify the presence of gender, and differential effects of biological maturity in their normative trajectories; and (3) describe the effects of time varying covariates; namely physical activity level and fatness

\section{SUBJECTS AND METHODS}

The sample comes from the 'Growth and Health Cariri Study', a mixed-longitudinal research about growth, sexual maturation and motor performance dynamics of children and adolescentes. Three main cities from Cariri Region, Ceará state, northeast region of Brazil were selected: Juazeiro do Norte, Crato and Barbalha. All participants were from public and private schools, and the sample consisted of four age cohorts: 8 , 10, 12, and 14 years at study entry. These cohorts were followed for three consecutive years with measurements taken at six-month intervals during the period 2006 - 2009. Due to the overlapping nature of the cohorts it was possible to develop developmental patterns from 8 to 16 years of age during a three year time period. The original sample comprised 796 children and youth (368 girls and 428 boys) (Table I). Student's socioeconomic status (SES) was defined according to family's average income and school attendance: private (high level) and public (low level). Sex and age specific sample sizes are given in Table I. The "Healthy Growth in Cariri Study" was approved by the Ethics Research Committee of the Medical School of Juazeiro do Norte and informed consent was obtained from parents and directors of all schools.

Table I. Sample size by age, cohorts and sex.

\begin{tabular}{ccccc}
\hline Cohort & Ages & Girls & Boys & Total \\
\hline C 1 & $08-10$ & 117 & 148 & 265 \\
C2 & $10-12$ & 96 & 87 & 183 \\
C 3 & $12-14$ & 111 & 124 & 235 \\
C4 & $14-16$ & 44 & 69 & 113 \\
\hline & Total & 368 & 428 & 796 \\
\hline
\end{tabular}




\section{Measurements and tests}

Skinfolds were measured by highly trained staff according to the procedures described by Claessens et al. (2008) at the following anatomical sides: triceps, subscapular, biceps, iliac, and calf. Due to skewed distributions, all were log transformed and summed in each subject at all measurement occasions. This sum is used as an indicator of fatness.

Strength was assessed with two tests taken from the American Alliance for Health, Physical Educations, Recreation and Dance (AAHPERD, 1980) test battery. The tests reflected two important components: static (hand grip) and power (standing long jump).

Bone age was estimated using the Tanner-Whitehouse method (TW3) (Tanner et al., 200 I). Radiographs were taken at the Radiology Department of the public hospital of Juazeiro do Norte. A radiograph of the left hand and wrist of each child was taken on a yearly basis over the three consecutive years. The difference between biological and chronological ages was calculated for each child at study entry. The classification scheme described by Malina et al. (2004) was used to divide children and youth into late maturers (difference greater than -1 year), average maturers (difference between $-\mathrm{I}$ and $\mathrm{I}$ year), and early maturers (difference greater than $+\mathrm{I}$ year).

Children's physical activity (PA) was estimated by direct interview (one-toone) using the Baecke questionnaire (Baecke, Burema \& Frijters, 1982), which is considered a valid and reliable instrument (Philippaerts \& Lefevre, 1998). This questionnaire consists of questions that call for Likert-type response $(I-5)$ and are designed to assess different categories of the concept of PA (work/school, sports and leisure-time). Sport index was scored, in part, from the two most frequently played sports (divided into three levels: low level for sports that average energy expenditure is $0.76 \mathrm{MJ} / \mathrm{h}$; middle level: $1.26 \mathrm{MJ} / \mathrm{h}$; and high level: $1.76 \mathrm{MJ} / \mathrm{h}$ ), for which the number of hours per week, month per year, and estimated frequency of sweating, and a subjective comparison of participation in exercise relative to others of the same age. Leisure time index was based on the frequency of television viewing, cycling, and time spent walking daily. In this study we used the sum of the sport index and the leisure time index to summarize the total physical activity level.

Data quality control was performed in two steps. In the first step a pilot study was implemented and all team members were trained and applied all testing procedures on a sample of 26 children, under the supervision of JM, AC and GB. Secondly, an in-field reliability procedure was implemented during data collection. Each day, a random sample of five children was retested. Intraclass correlation coefficients (R) were high for the two strength tests: 0.95 (hand grip), and 0.96 (stand long jump). The Baecke questionnaire was also re-assessed in a random sample of 105 children and youth from both genders and all cohorts. The intraclass correlation for total physical activity was 0.82 (sport score $\mathrm{R}=0.8 \mathrm{I}$ and leisure time $\mathrm{R}=0.78$ ). Technical error measurement for skinfolds varied from 0.4 to $0.7 \mathrm{~mm}$. The first author (SS) 
rated all radiographs. Training and quality control procedures were described in detail elsewhere (Silva et al., 2010). In brief, we randomly re-assessed a total of II0 radiographs (intra-observer reliability). Agreements/disagreements in assigning bone stages for each of the 13 bones were verified. Agreements varied from $74.6 \%$ (for distal phalanx I) to $90.9 \%$ (proximal phalanx III). Overall agreement was $84.9 \%$.

Descriptive statistics were computed in SPSS version 18.0. Modeling changes in strength performance were performed with HLM 6.0 software within the framework of the multilevel approach (Bryk \& Raudenbush, 1987). Maximum likelihood estimation procedures were used to assess intra-individual changes as well as average motor performance. In HLM analysis, the number and spacing of measurement observations may vary across persons. It can also easily accommodate data from mixed-longitudinal designs with missing data under the assumption that missing is at random (Hox, 20l0). To best describe individual longitudinal trajectories, average trajectories and respective predictors, a stepwise procedure was adopted. We first defined the level- I model using up to a $3^{\text {rd }}$ degree polynomial of age. To facilitate the interpretation of model parameters describing change, age was centered at 12 years which is, on average, the age at peak height velocity in girls and the age at onset of the growth spurt in boys (Malina, Bouchard \& Bar-Or, 2004). A series of hierarchically nested level-I models were fitted with increasing patterns of change (linear, quadratic, cubic). Deviance statistic, as a measure of model quality, was compared in such models, and the one with lower Deviance was retained showing the best fit based on the evidence that the Chi-square value related to this decrease was statistically significant. The next step was to include time varying covariates: total physical activity and sum of skinfolds (fatness) each available at every six points of data collection. Only statistically significant predictors were allowed to enter the model. Finally, time invariant predictors (level-2) were included in the best fitting model describing change: sex, and a dummy coding (DI and D2) of biological maturation (late, on time, early) assessed at the first measurement occasion.

\section{RESULTS}

Intraindividual trajectories in hand grip were best described by a $2^{\text {nd }}$ degree polynomial (see Figure I panel a). The average curves for boys and girls are presented in Figure I panel b. 

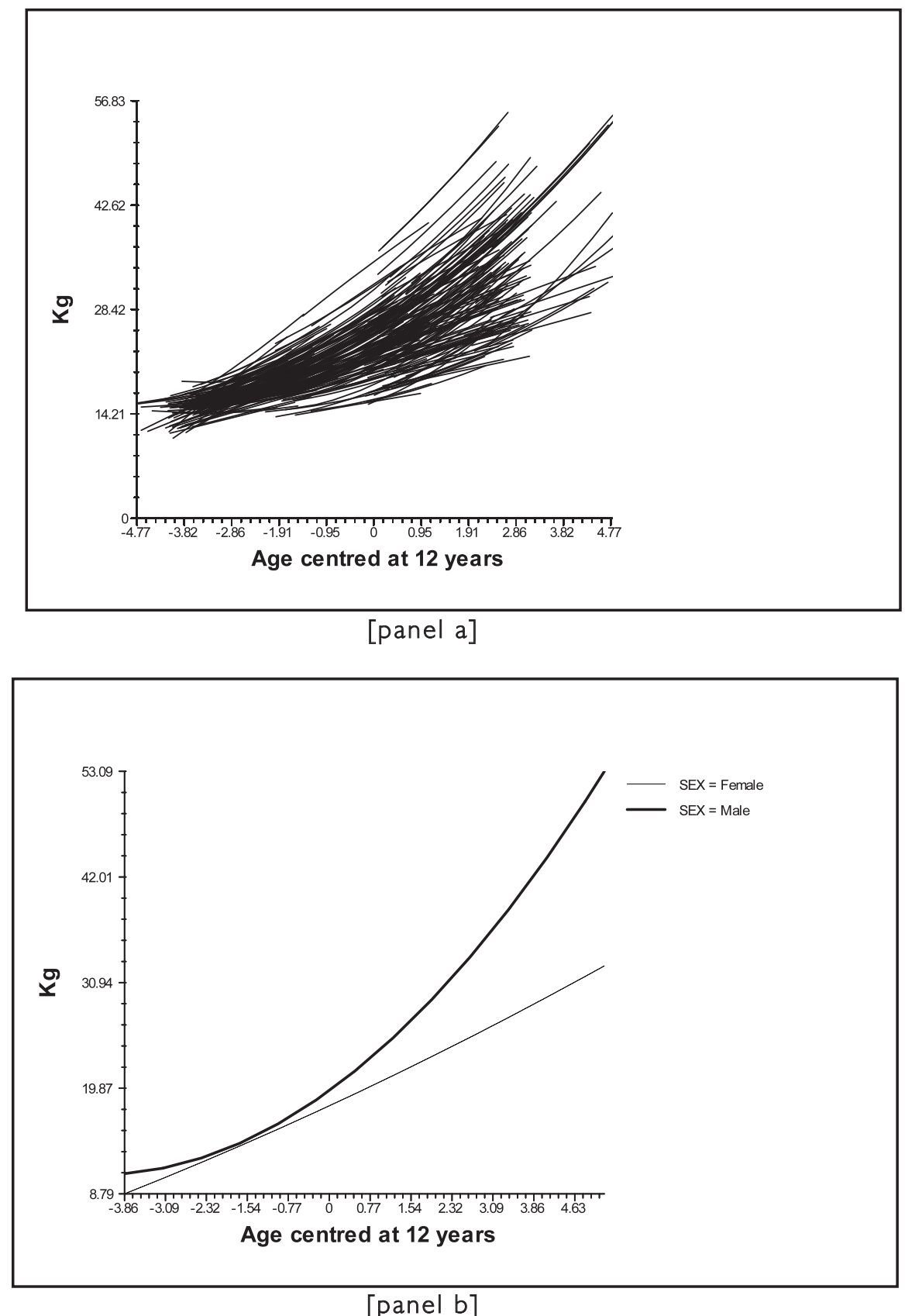

Figure I. Intraindividual trajectories of all subjects for hand grip (panel a) and average curve by sex (panel b). 
Results of the best fitting models are displayed in Table 2. Average hand grip strength of 12 year-old girls was $18.26( \pm 0.49) \mathrm{kg}$. Boys were, on average, $1.58( \pm 0.57) \mathrm{kg}$ stronger. At 12 years, late maturers are less strong $(-2.40 \pm 0.65 \mathrm{~kg})$ than advanced ones $(3.56 \pm 1.00 \mathrm{~kg})$. Per year, girls increase their strength at the rate of $2.5 \mathrm{l} \mathrm{kg} /$ year $( \pm 0.15)$, but boys did so at a higher rate $(3.98 \mathrm{~kg} /$ year: $2.5 \mathrm{I}+1.47)$.

Late maturers had a linear rate of growth similar to that of average maturers, but early maturing subjects handgrip performance increased at a higher rate (3.44 $\mathrm{kg} /$ year $=2.55+0.93)$. While in girls the quadratic component was not significant ($0.003 \pm 0.06)$, in boys such an upward trend in strength development was evident $(0.41 \pm 0.08)$. Maturity advanced youths (Figure 2$)$ showed greater strength gains, while for late maturers (Figure 3) the strength trajectories were similar to average maturers.

Table 2. Fixed and random-effects estimates for the best fitting growth curve model of hand grip.

\begin{tabular}{|c|c|c|c|c|}
\hline Fixed-effects estimates & Coefficient & $\begin{array}{c}\text { Standard } \\
\text { error }\end{array}$ & T-ratio & P-value \\
\hline Intercept ( 12 years) & 18,26 & 0.49 & 37.45 & $<0.001$ \\
\hline Sex & 1.58 & 0.57 & 2.76 & 0.007 \\
\hline Late maturers (DI) & -2.40 & 0.65 & -3.67 & $<0.001$ \\
\hline Early maturers (D2) & 3.56 & 1.00 & 3.56 & 0.001 \\
\hline Linear Slope & 2.51 & 0.15 & 16.70 & $<0.001$ \\
\hline Sex & 1.47 & 0.20 & 7.25 & $<0.001$ \\
\hline Late maturers (DI) & -0.09 & 0.23 & -0.41 & 0.684 \\
\hline Early maturers (D2) & 0.93 & 0.42 & 2.21 & 0.028 \\
\hline Quadratic Slope & -0.003 & 0.06 & -0.06 & 0.953 \\
\hline Sex & 0.41 & 0.08 & 5.32 & $<0.001$ \\
\hline Late maturers (DI) & 0.26 & 0.09 & 2.87 & 0.005 \\
\hline Early maturers (D2) & -0.13 & 0.13 & -0.99 & 0.322 \\
\hline Fatness & 0.99 & 0.22 & 4.50 & $<0.001$ \\
\hline Total Physical Activity & - & & & \\
\hline Random-effects estimates & $\begin{array}{c}\text { Variance } \\
\text { component }\end{array}$ & & Chi-square & P-value \\
\hline Intercept & 13.26 & & 734.448 & $<0.001$ \\
\hline Linear Slope & 0.48 & & 338.726 & 0.001 \\
\hline Residual & 8.18 & & & \\
\hline Correlation (Intercept/LinearSlope) & 0.98 & & & \\
\hline Deviance & 5286.88 & & & \\
\hline Parameters & 17 & & & \\
\hline
\end{tabular}




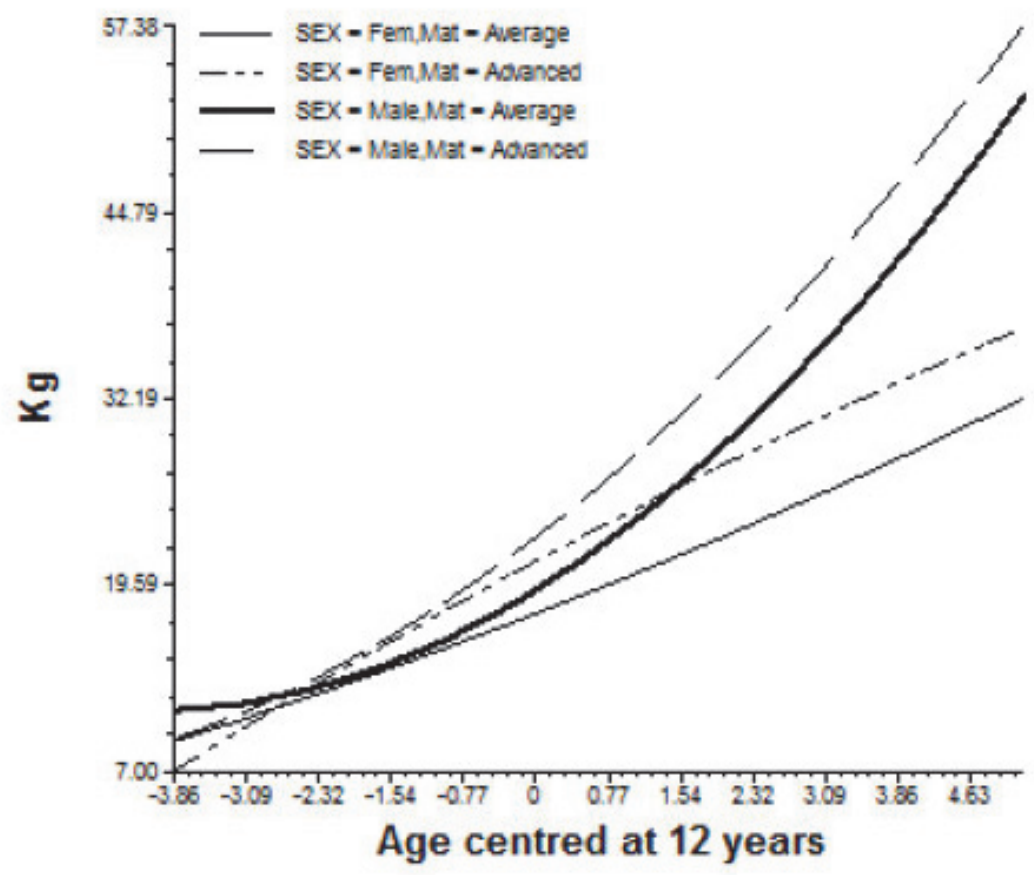

Figure 2. Strength (handgrip) trajectories of boys and girls of contrasting maturity status: average maturers versus early maturers.

Total physical activity did not show any longitudinal association with static strength development, whereas total body fat had a significant positive association (0.99 \pm 0.22$)$. Statistically significant interindividual differences were present at 12 years (I 3.26); the same occurred for the linear rates of change $(0.48)$ in force production. No such trend was present in the curvilinear part of the trajectories. 


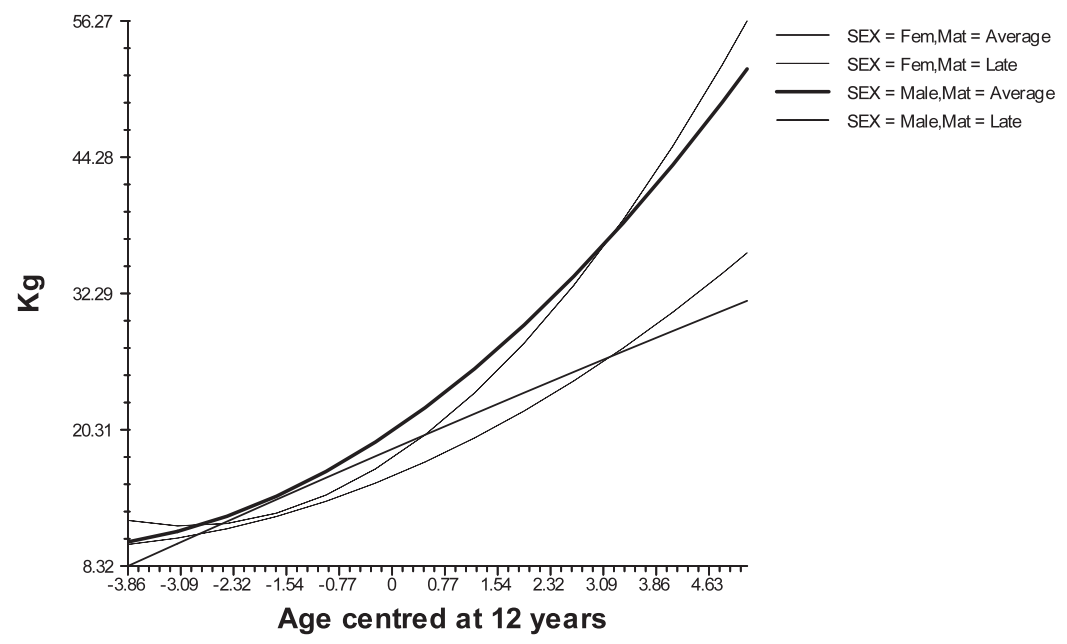

Figure 3. Strength (handgrip) trajectories of boys and girls of contrasting maturity status: (average maturers versus late maturers).

Figure 4 (panel a) shows the intraindividual changes in standing long jump (SLJ), and panel b, presents average curves for boys and girls. A general $2^{\text {nd }}$ degree polynomial of time was the best descriptor of changes.

Table 3 and Figure 4 summarize information from the best fitting model with time varying and time invariant covariates. On average, a girl of 12 years jumped $137.52( \pm 0.85) \mathrm{cm}$. Boys performed $10.23( \pm 2.17) \mathrm{cm}$ better. At 12 years of age, late and early maturers had a lower $(-4.19 \mathrm{~cm})$ performance compared to average maturers although this difference was not statistically significant. Per year, the rate of change in explosive strength in girls was $2.56(0.86) \mathrm{cm} /$ year, but in boys it was $(2.56+5.68=8.24 \mathrm{~cm})$. Late and early maturers did not have significant differences in the linear rate of change in SLJ. While an upward trend (quadratic effect) was not evident in girls, in boys such trend was evident $(1.20 \pm 0.33 \mathrm{~cm})$. No specific maturational effect were presented in the non-linear effect of SLJ changes. Subjects with higher body fat had, in longitudinal terms, a negative association $(-3.4 I \pm 0.69 \mathrm{~cm})$ with SLJ performance, whereas total physical activity had a positive association $(1.76 \pm 0.59 \mathrm{~cm})$. At baseline ( 12 years of age), a statistically significant interindividual difference was found among subjects, and the same occurred for the linear part of power changes. At 12 years, those who performed better had also the greater rates of linear change in SLJ $(r=0.25)$. 
Table 3. Fixed and random-effects estimates for growth curve models of standing long jump..

\begin{tabular}{lcccc}
\hline Fixed-effects estimates & Coefficient & $\begin{array}{c}\text { Standard } \\
\text { error }\end{array}$ & T-ratio & P-value \\
\hline Intercept (I2 years) & 137.62 & 1.85 & 74.24 & $<0.00$ I \\
Sex & 10.23 & 2.27 & 4.51 & $<0.00$ I \\
Late maturers (DI) & -4.19 & 2.41 & -1.74 & 0.082 \\
Early maturers (D2) & -4.19 & 3.63 & -1.16 & 0.249 \\
Linear Slope & 2.56 & 0.86 & 2.97 & 0.004 \\
Sex & 5.68 & 1.01 & 5.60 & $<0.00$ I \\
Late maturers (DI) & 1.14 & 1.08 & 1.05 & 0.294 \\
Early maturers (D2) & 1.85 & 1.34 & 1.38 & 0.170 \\
Quadratic Slope & -0.30 & 0.25 & -1.21 & 0.229 \\
Sex & 1.20 & 0.33 & 3.66 & $<0.00$ I \\
Late maturers (DI) & 0.12 & 0.41 & 0.28 & 0.779 \\
Early maturers (D2) & 0.12 & 0.48 & 0.25 & 0.807 \\
Fatness & -3.41 & 0.69 & -4.95 & $<0.00$ I \\
Total Physical Activity & 1.76 & 0.59 & 2.97 & 0.004 \\
\hline Random-effects estimates & Variance & & Chi -square & P-value \\
& component & & & \\
\hline Intercept & 252.34 & & 996.977 & $<0.001$ \\
Linear Slope & 9.02 & & & $<0.001$ \\
Residual & $\mid 13.99$ & & & \\
Correlation & 0.25 & & & \\
Intercept/LinearSlope) & & & & \\
\hline Deviance & 9108.67 & & & \\
Parameters & 18 & & &
\end{tabular}



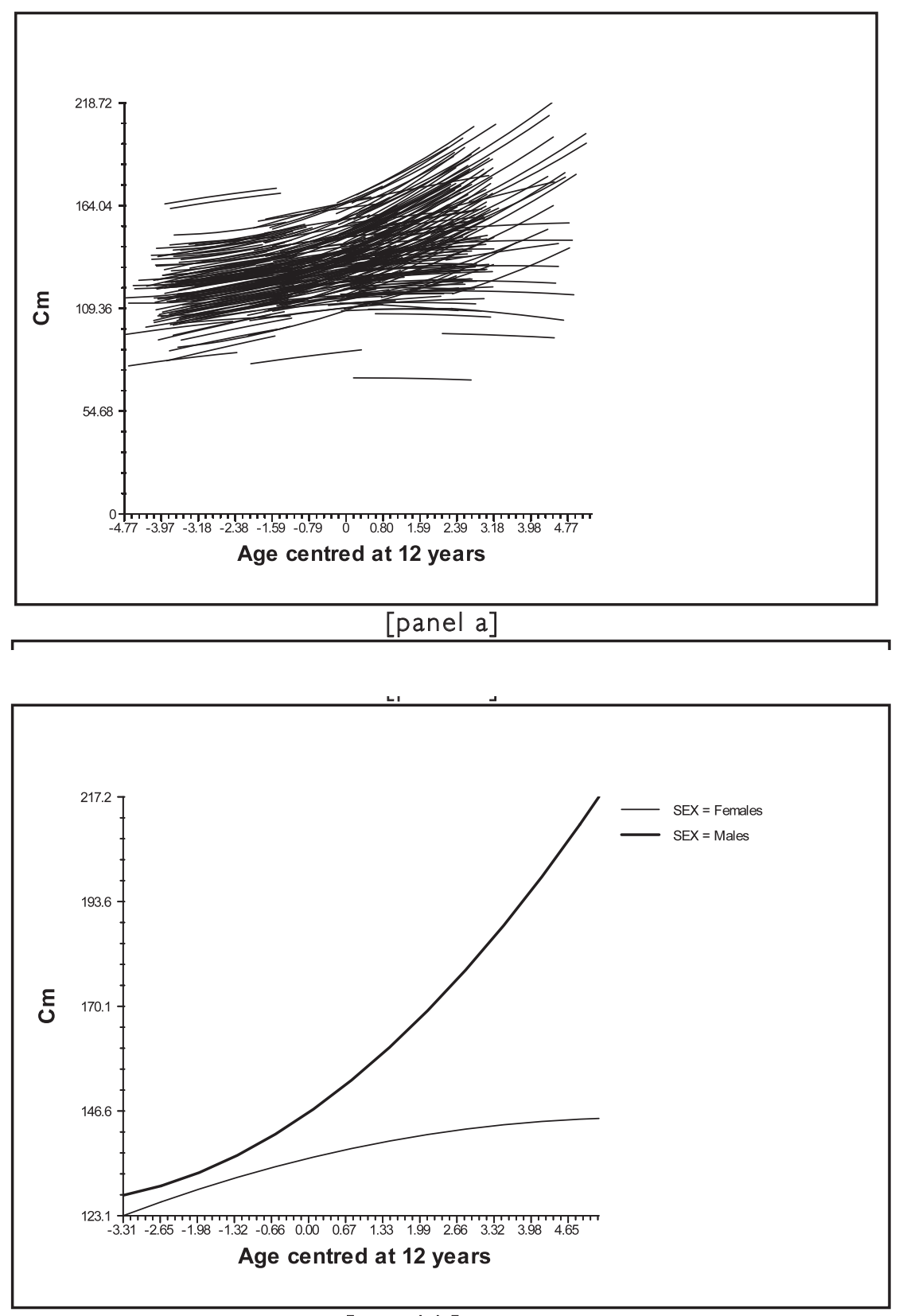

\section{[panel b]}

Figure 4. Intraindividual trajectories of all subjects for standing long jump (panel a) and average curve by sex (panel b). 


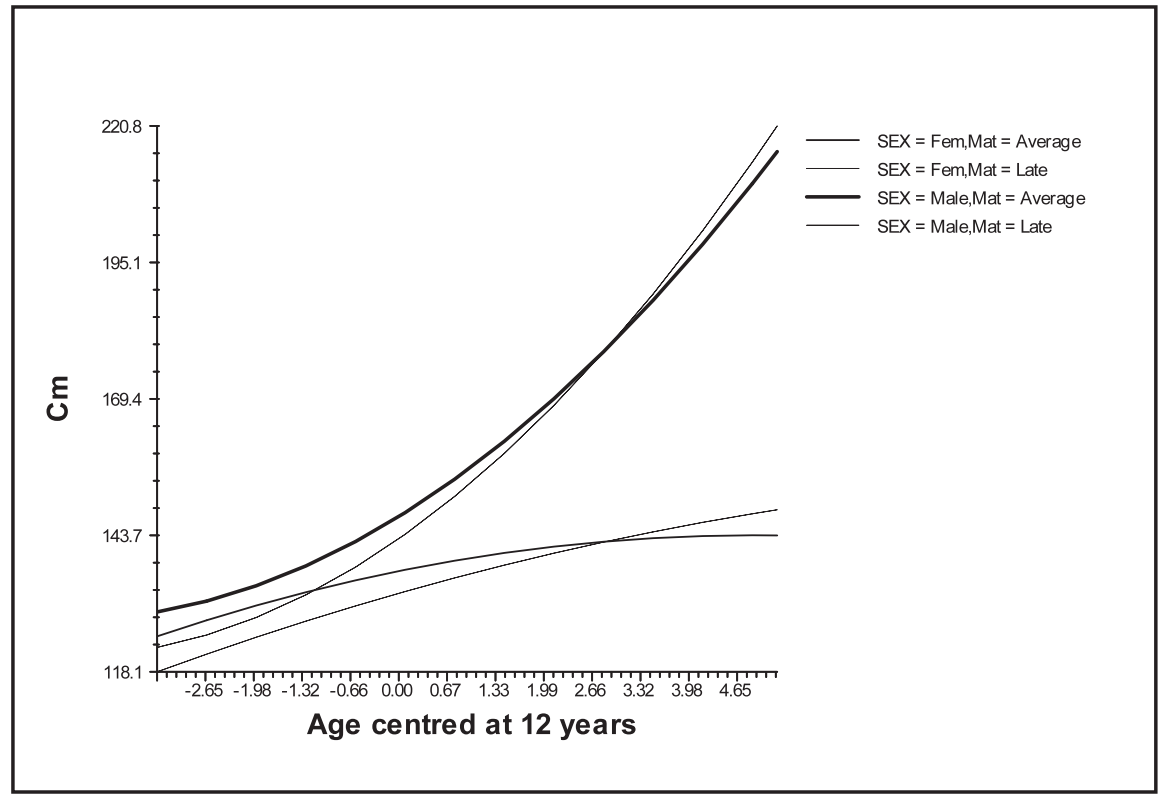

Figure 5. Srength (standing long jump) trajectories of boys and girls of contrasting maturity status: average maturers versus late maturers

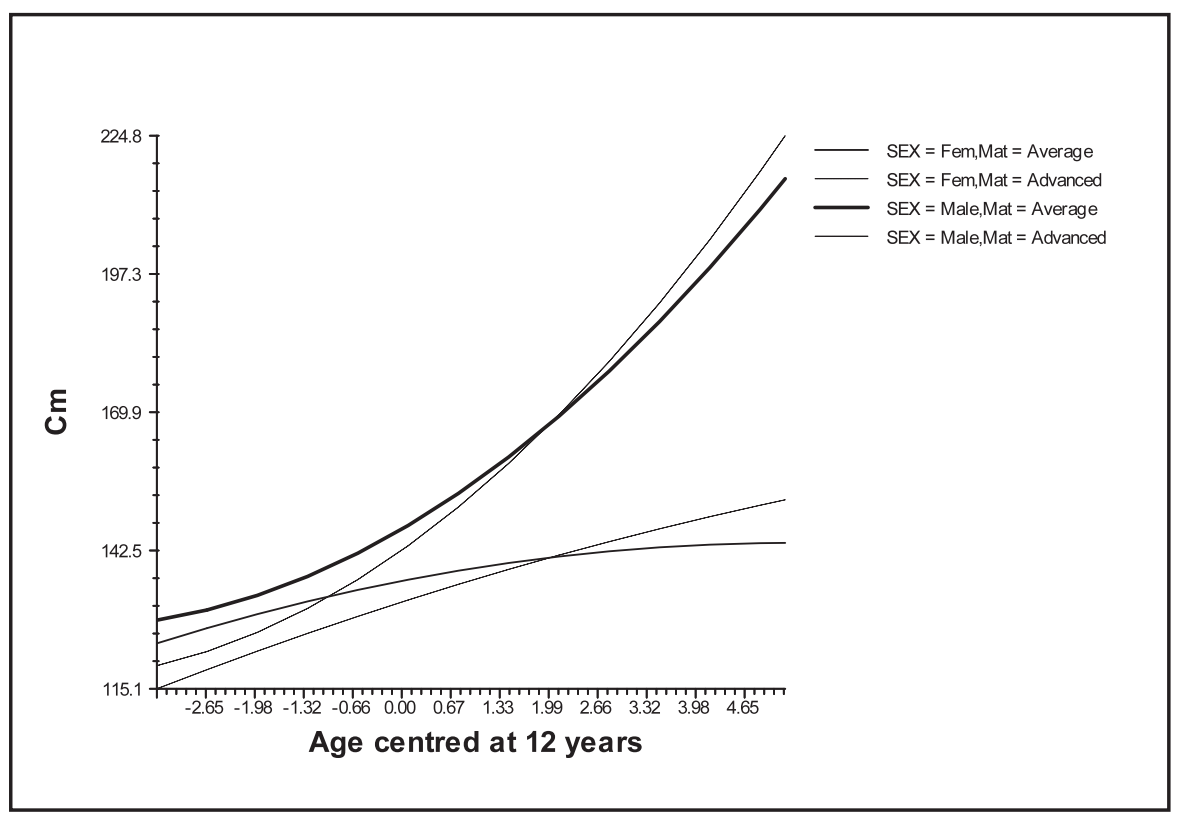

Figure 6. Srength (standing long jump) trajectories of boys and girls of contrasting maturity status: average maturers versus advanced maturers 


\section{DISCUSSION}

The main aim of this study was to model longitudinal changes in strength development of children and youth from Cariri, Brazil. We also assessed the importance of physical activity levels and fatness on strength development. Furthermore, we also intended to verify the significant presence of gender, as well as, the differential effects of biological maturity in their strength trajectories.

Cariri boys were found to be stronger and jump further than girls. The growth trajectories were also different: boys had non-linear growth trajectories in static and explosive strength, while girls had linear trends. Variation at baseline, i.e., 12 years of age, is highly pronounced in standing long jump and hand grip strength, which is indicative of significant heterogeneity among subjects of both sexes in strength status; similar inter individual differences were noticed for their slopes, i.e., velocity in strength development. This variation, not only at 12 years of age, but also in strength changes may be explained by marked differences in timing and tempo of their growth spurts. Physical activity as a time-varying predictor was not independently associated with static strength, but it was associated with explosive strength (standing long jump). Fatness was a significant independent positive predictor of static strength, but it was negatively associated with explosive strength. Maturity was positively associated with static strength but not with explosive strength.

Although recent longitudinal data about strength performance in boys and girls followed from 8 to 16 years is lacking, our most important body of information relies on studies conducted some 20-30 years ago. At that time no novel statistical modeling strategies, fast algorithms and sophisticated software was available. However, highly relevant descriptions and interpretation emerged from distance and velocity curves, as well as from aligning data according to age at peak height and weight velocities. A great deal of this body of data comes primarily from USA (Branta, Haubenstricker \& Seefeldt, 1984; Espenschade, 1940; Jones, 1949), Canada (Carron \& Bailey, 1974) and Belgium (Beunen et al., 1988). No such longitudinal information is available in children and youth from South American countries, namely in Brazil, where socio-economic disparities are widely common (Ulijaszek, 2006; UNDP, 2009). The sex differences and growth trajectories of Brazilian youths studied herein follow closely the growth characteristics described earlier. Sex differences in strength between boys and girls become more pronounced at the beginning of the adolescent period. The marked acceleration of strength performance during the male adolescent growth spurt magnifies the sex difference which is somewhat linked to greater increases in muscle mass in males (Beunen \& Malina, 1988). In the Cariri sample, average strength curves continue to increase more rapidly for boys than for girls, suggesting strength spurt in boys, but not in girls. A leveling off is to be expected earlier in girls than in boys, despite the fact that present data only cover the period till 16 years of age. Although in most growth studies data collection is usually terminated at 18 years of age, it has been shown that strength continues to increase until the third decade of life. This trend was empirically confirmed in a subsample of the longitudinal series of Belgium boys that were measured again at 30 years of age. Significant increases in strength occurred between 18 and 30 years (Lefevre et al., 1990). However, the differences among early-maturing, average-maturing and late-maturing boys in static strength vanished at 30 years. These findings emphasize the continued growth in strength of 
late-maturing boys and transient nature of maturity associated variation in performance during adolescence.

Physical activity as a time-varying predictor was not longitudinally associated with static strength, but was with explosive strength (standing long jump). Associations between physical fitness components in adolescent boys and girls and hours of physical activity, total daily energy expenditure, energy expenditure in moderate-tovigorous physical activity and inactivity (television viewing time) are usually low. For example, a cross-sectional Canadian study (Katzmarzyk et al., 1998) involving 9 to 18 year-old boys and girls, provided some evidence of the relationship between several components of physical activity and physical fitness using a multivariate approach (canonical correlation). Results showed that $11 \%$ to $21 \%$ of the common variance space arise from health-related physical fitness (sit up's, static leg strength and power), physical activity and the sum of six skinfolds. However, the large amount of the variability, about $80 \%$ to $90 \%$ in health-related fitness, was not accounted for by physical activity or inactivity. Similarly, but using a different design, Belgian boys followed longitudinally for 6 years from 12 to 18 years and classified as active and inactive did not differ in static strength and power (Beunen et al., 1992). The same trend was observed in Dutch children (Verschuur, 1987) followed longitudinally from 13 to 16 years of age who were also divided in active and non active boys. No significant different trajectories among activity groups in static arm strength, sit-andreach, vertical jump and speed of upper limb movement were identified. These result suggest that to a certain extent strength development in childhood and youth are related to normal growth and development and to a lesser degree exposure to PA.

Fatness was a significant positive predictor of static strength, but a negative predictor for explosive strength. It has been widely shown in cross sectional studies that fatness is negatively associated with the motor performance, although the magnitude of these correlation varies considerably (Malina, Bouchard \& Bar-Or, 2004). It is easily understood that fat represents an inert mass that adversely affects those motor tasks that require jumping (as standing long jump), running (dashes) of lifting of the body (pull-ups).

Although differences in socio-economic status may act with a gradient spectrum in physical fitness in children and youth (Eiben \& Mascie-Taylor, 2004; Sallis et al., 1996) no such trend was evident in the Cariri subjects despite the fact that this region may be best described as having a low socio-economic level when compared to others Brazilian regions or industrialized countries.

At 12 years, late maturing youngsters from Cariri are less strong (handgrip) than their advanced peers. However, in SLJ both late and early maturers did not differ significantly in the linear rate of change. These major trends in hand grip and SLJ are seen after adjustments for longitudinal association with physical activity and body fatness. It has been consistently shown that the associations (Beunen et al., 1992; Beunen et al., 1981; Malina, Bouchard \& Bar-Or, 2004) between maturity and strength performance are positive during the adolescent period. In Canadian boys (Carron \& Bailey, 1974), early maturers had significantly greater strength than late maturers of the same chronological age. When strength was divided by body height, results remained unchanged. However, when the effects of weight were factored out, differences 
disappeared. In the mixed-longitudinal sample of the Adolescent Growth Study in Oakland, California, early maturing boys were stronger at all ages than average and late maturers. In girls, early maturers tend to be slightly stronger only early in adolescence, but as adolescence continues, the differences among maturity groups are reduced (data reviewed by Malina et al, 2004). Similar results are found in Portuguese children participating in the 'Madeira Growth Study' (Freitas et al., 2002), in which 507 boys and girls were followed for three consecutive years. Boys from the early maturing group (classification based on skeletal maturity) had higher mean values in hand grip and standing long jump than either on time or late maturers. Early maturing girls showed the same trend as in boys in the hand grip, but not in the standing long jump.

Little et al. (1997) studied 6 I Canadian girls aged 10 to 14 years who were followed for 3 years. Functional strength, explosive strength and static strength improved significantly with age and sexual maturation. Generally more mature girls tended to perform significantly better than the less mature for the same chronological age. The results from contrasting maturity groups have been confirmed by correlational analyses. More comprehensive analyses considering the interactions between chronological age, skeletal age, height, and weight indicate that variation in maturity status influences strength characteristics indirectly. Skeletal maturity influenced strength mainly through its interaction with body mass and height (Beunen \& Malina, 2008).

Notwithstanding the data quality control, the careful design and sophisticated data analysis this study has limitations: ( I ) total physical activity was assessed using a self-reported questionnaire. It is possible that subjects do not recall their activities accurately. To minimize this possible bias the questionnaire was completed with the assistance of a trained interviewer. This allows a higher reliability than self-reported methods in children (Corder et al., 2008); (2) the difficulty of comparisons of present data with other state or national studies, due to the absence of longitudinal information about strength performance of schoolchildren in South America. Despite these limitations, the study was driven by important factors that we consider relevant: (I) the sample size and representativeness in terms of age groups and sex; (2) biological age was estimated by a trained observer and use of the latest version of TW3 Method; and (3) the statistical analysis technique to fit strength curves using time-varying and invariant covariates.

In summary, strength increases differently in boys (non linear) and in girls (linear). At 12 years, marked interindividual differences are observed in both sexes. Biological maturity is significantly different only in static strength. Physical activity is a significant predictor only in SLj; fatness is significantly associated to static strength development, although is negatively linked to explosive strength.

\section{REFERENCES}

AAHPERD., 1980, American Alliance for Health, Physical Educations, Recreation and Dance. Health Related Physical Fitness Manual. Washington, DC.

Baecke, J.A., Burema, J. and Frijters, J. E., 1982, A short questionnaire for the measurement of habitual physical activity in epidemiological studies. American Journal of Clinical Nutrition., 36(5), pp. 936-942. 
Baxter-Jones, A.D.G., Sherar, L.B. and Eisenmann, J.C., 2005, Controlling for Maturation in Pediatric Exercise Science. Pediatric Exercise Science, 17, pp. I8-30.

Beunen, G. and Malina, R., 1988, Growth and physical performance relative to the timing of the adolescent spurt. Exercise and Sport Science Reviews, 16, pp. 503-540.

Beunen, G. and Malina, R., 2008, Growth and biologic maturation: Relevance to athletic performance. In The Young athlete. Encyclopaedia of Sports Medicine (Vol. XII pp. 3-17)., edited by H. Ebestreit H. and Bar-Or, O., Malden: Blackwell.

Beunen, G., Malina, R., Renson, R., Simons, J., Ostyn, M. and Lefevre, J., 1992, Physical activity and growth, maturation and performance: a longitudinal study. Medicine and Science in Sports and Exercise, 24(5), pp. 576-585.

Beunen, G., Malina, R., Van't Hof, M., Simons, J., Ostyn, M., Renson, R. and Van Gerven, D., 1988, Adolescent Growth and Motor Performance. A Longitudinal Study in Belgian Boys. Illinois: Human Kinetics.

Beunen, G., Ostyn, M., Simons, J., Renson, R. and Van Gerven, D., 1981, Chronological and biological age as related to physical fitness in boys 12 to 19 years. Annals of Human Biology, 8(4), pp. 321-331.

Branta, C., Haubenstricker, J. and Seefeldt, V., 1984, Age changes in motor skills during childhood and adolescence. Exercise and Sport Sciences Reviews, I2, pp. 467520.

Bryk, A.S. and Raudenbush, S.W., 1987, Application of Hierarquical linear models to assessing change. Psychological Bulletin, I 0 I (I), pp. I47-I 58.

Carron, A. V. and Bailey, D.A., 1974, Strenght development in boys from 10 through 16 years. Monographs of the Society for Research in Child Development, 39(4), pp. $1-37$.

Claessens, A., Beunen, G. and Malina, R., 2008, Antropometry, physique, body composition, and maturity. In Paediatric Exercise Science and Medicine ( $2^{\circ} \mathrm{ed}$.), edited by Armstrong N. and Van Mechelen W., New York: Oxford University Press.

Corder, K., Ekelund, U., Steele, R.M., Wareham, N.J. and Brage, S., 2008, Assessment of physical activity in youth. Journal of Applied Physiology, I 05(3), pp. 977-987.

Eiben, O. G. and Mascie-Taylor, C.G.N., 2004, Children's growth and socio-economic status in Hungary. Economics \& Human Biology, 2(2), pp. 295-320.

Espenschade, A., 1940, Motor Performance in Adolescence. Including the Study of Relationships with Measures of Physical Growth and Maturity (Vol. V). Washington, DC: Society for Research in Child Development.

Freitas, D.L., Maia, J.A., Beunen, G., Lefevre, J.A., Claessens, A.L., Marques, A.T., Rodrigues, A.L., Silva, C.A., Crespo, M.T. and Thomis, M., 2002, Crescimento Somático, Maturação Biológica, Aptidão Física, Actividade Física e Estatuto SócioEconômico de Crianças e Adolescentes Madeirenses - O Estudo de Crescimento da Madeira: SAEFD Universidade da Madeira.

Hox, J...,2010, Multilevel analysis: technics and applications $\left(2^{\circ}\right.$ ed.). East Sussix: Routledge

Jones, H.E., 1949, Motor performance and growth: A developemental study of static dynamometric strength. Berkeley: University of California Press. 
Katzmarzyk, P.T., Malina, R.M.., Song, T.M. and Bouchard, C., 1998, Physical activity and health-related fitness in youth: a multivariate analysis. Medicine and Science in Sports and Exercise, 30(5), pp. 709-7।4.

Lefevre, J., Beunen, G., Steens, G., Claessens, A. and Renson, R., 1990, Motor performance during adolescence and age thirty as related to age at peak height velocity. Annals of Human Biology, I 7, pp. 423-435.

Little, N.G., Day, J.A.P. and Steinke, L., 1997, Relationship of Physical Performance to Maturation in Perimenarchal Girls. American Journal of Human Biology, 9(2), pp. |63-17|.

Maia, J.A., Garganta, R., Seabra, A., Lopes, V., Vinagre, J., Freitas, D., Prista, A. and Meira Jr., C., 2005, Dados Longitudinais e Modelação Hierárquica. Um Tutorial para Investigadores das Ciências do Desporto. Rev. Bras. Cineantropom. Desempenho Hum., 7(2), pp. 94-108.

Malina, R., Bouchard, C. and Bar-Or, O., 2004, Growth, Maturation and Physical Activity (4 $4^{\mathrm{a}}$ ed.). Illinois: Human Kinetics Books.

Philippaerts, R. and Lefevre, J., 1998, Reliability and validity of three physical activity questionnaires in Flemish males. American Journal of Epidemiology, 147(10), pp. 982.

Sallis, J.F., Zakarian, J.M., Hovell, M.F. and Hofstetter, C.R., 1996, Ethnic, socioeconomic, and sex differences in physical activity among adolescents. Journal of Clinical Epidemiology, 49 (2), pp. 125- I 34.

Silva, S.P., Freitas, D., Beunen, G. and Maia, J.A., 2010, Biological maturation: it's relevance to learning the TW3 method. Rev. Bras. Cineantropom. Desempenho Hum., I 2(5), pp. 352-358.

Tanner, J., Healy, M., Goldstein, H. and Cameron, N., 200I. Assesment of Skeletal Maturity and Prediction of Adult Height. (TW3 method). London: W.B Saunders.

Ulijaszek, S., 2006, The International Growth Standard for Children and Adolescents Project: Environmental Influences on Preadolescent and Adolescent Growth in Weight and Heigth. Food Nutr Bull, 27(4), pp. S279-S294.

UNDP., 2009, United Nations Development Programme - Human Development Report 2009. from http://hdrstats.undp.org/en/countries/

Verschuur, R., 1987, Daily Physical Activity: Longitudinal changes during the teenage period. Haarlem, The Netherlands Uitgeverrij de Vrieseborch. 